\title{
Isolation of sulfur oxidizing bacteria from polluted water and screening for their efficiency of sulfide oxidase production
}

\author{
Yousef N.*, Mawad A., Aldaby E. and Hassanein M. \\ Department of Botany \& Microbiology, Faculty of Science, Assiut University, 71516 Assiut, Egypt \\ Received: 09/05/2018, Accepted: 19/11/2018, Available online: 21/11/2018 \\ *to whom all correspondence should be addressed: e-mail: naeima@aun.edu.eg \\ https://doi.org/10.30955/gnj.002756
}

\begin{abstract}
Presence of sulfide in the environment represents huge concerns to biological life. The high costs and low safety of chemical and physical removal strategies lead to finding alternative strategies. Sulfur-oxidizing bacteria (SOB) are consider a promising alternative strategy, where they play a critical role in removal of such compounds from water and soil environments, as well as, they maintain the sulfur balance during natural sulfur cycle. The main objective of this study was to isolate sulfur oxidizing bacteria (SOB) from sulfide polluted water. In addition screening for sulfide oxidase producer bacteria was performed. Twenty isolates of sulfur oxidizing bacteria were isolated from eight different sulfide polluted water sources. During testing the isolates on thiosulfate broth medium, it was observed that, eleven isolates could efficiently reduce the $\mathrm{pH}$ of the media from $7.5 \pm 0.2$ to $5.0 \pm 0.5$ as a resulting of the oxidizing of sulfides to sulfate ion. The concentration of produced sulfate ion ranged from 76 to $155 \mathrm{mg} / \mathrm{mL}$. The sulfur oxidase activity of the tested isolates ranged between 2.68 to $5.23 \mathrm{U} / \mathrm{mL}$. The bacterial isolates were identified as Bacillus spp., Pseudomonas spp. and Klebsiella spp. based on their morphological and biochemical characterization.
\end{abstract}

Keywords: Sulfur-oxidizing bacteria, polluted water, biochemical characterization, sulfide oxidase, sulfate ion.

\section{Introduction}

Sulfide is generated as one of the waste chemicals in some industries, such as tanneries, rayon textile production, paper manufacturing, liquefied petroleum gas plants, petroleum and natural gas extractions and refining, agricultural and waste disposal produced inorganic sulfur compounds to the environment as by products (Park et al., 2002). In nature, sulfur compounds are formed during various reactions, such as through volcanic eruptions, bacterial processes, evaporation of water or decay of dead organisms. Serious problems of sulfur are in reduced form as sulfides (Roth et al., 1995). Hydrogen sulfide is widely known as the most undesirable component of biogas that causes not only serious sensory and toxic problems, but also corrosion of concrete and steel structures (Ruby et al., 1981). Pulping site, petroleum refinery plant, sewage treatment facility and livestock rising farm emit very offensive odors and most of them contain sulfur compounds (Park et al., 2002). Sulfides are detrimental agents in the environment because of their toxicity to human health and corrosive effect on concrete and metallic infrastructure, in addition to their strong unpleasant smell (Oprime et al., 2001). Therefore, removal of sulfur compounds especially in the waste is necessary. Biological sulfide oxidation is currently the most widely used process for the treatment of sulfide wastewater (Liao et al., 2008; Sorokin et al., 2008). The oxidation reactions are performed mainly by sulfur oxidizing prokaryotes from the domains Archaea and Bacteria (Friedrich et al., 2001). Recently, many new biotechnological approaches have been developed based on the biogeochemical cycle of sulfur in nature. Thus, sulfur-oxidizing bacteria play a critical role in these technologies (Pokorna and Zabranska, 2015).

Sulfur-oxidizing bacteria (SOB) play a vital role in bioremediation of sulfide-rich wastewater (Luo et al., 2011). Distribution and abundance of SOB responsible for sulfide oxidation are of great importance for optimization of the treatment systems for sulfide biological degradation (Luo et al., 2011). Different species of SOB apply several enzymes, pathways, and mechanisms of electron transport and energy conservation for oxidation of sulfide. Sulfur-oxidizing (Sox), dissimilatory sulfite reductase (Dsr), and sulfide quinone oxidoreductase (SQR) enzyme systems have been reported to associate with sulfide oxidation (Friedrich et al., 2001; Sander et al., 2006; Chan et al., 2009).

Sulfide oxidase produced by sulfur-oxidizing bacteria (SOB) can be useful in deodorizing farm animal feces (Yun and Ohta, 1997), mitigation of sulfides from effluent streams (Visser et al., 1997), landfills, wastewater facilities and also oil-field brine (Gevertz et al., 2000). Graves et al. 2017 used natural consortium of SOB to convert reduced sulfur compounds to commercial valuable gypsum enriched product. Pokorna and Zabranska 2015 revealed that the sulfur oxidizing bacteria could remove the hazardous sulfides in water or gaseous phase. 
Sulfur oxidizing bacteria (SOB) are capable of oxidizing sulfide to elemental sulfur $\left(S^{0}\right)$ by partial oxidation, or sulfate $\left(\mathrm{SO}_{4}{ }^{2-}\right)$. Also, hydrogen sulfide $\left(\mathrm{H}_{2} \mathrm{~S}\right)$, thiosulfate $\left(\mathrm{S}_{2} \mathrm{O}_{3}{ }^{2-}\right)$ and tetrathionate $\left(\mathrm{S}_{4} \mathrm{O}_{6}{ }^{2-}\right)$ can be converted to sulfate. Oxidation of sulfide and intermediate sulfur compounds by SOB are crucial for bioleaching and the removal of $\mathrm{H}_{2} \mathrm{~S}$ from polluted water. The majority of heterotrophic SOB bacteria belong to the genera Pseudomonas, Xanthomonas, Halomonas, Escherichia coli and Klebsiella (Gommers and Kuenen, 1988).

The main objective of this study is to isolation and identification of potential sulfur-oxidizing bacteria (SOB) from polluted water samples and screening of sulfide oxidase activity and sulfate ion produced by isolated strains. In addition to, the optimization of thiosulfate oxidation and sulfate ion production by SOB4 is a novel strategy to understand the microbial metabolism of sulfur in polluted water.

\section{Materials and methods}

\subsection{Collection of samples}

Eight water samples were collected from different polluted water sources (sewage and industrial wastes) in Assiut Governorate, Egypt. The samples were collected in clean and sterilized bottles and stored at $4 \pm 0.1^{\circ} \mathrm{C}$ in a refrigerator for bacterial studies.

\subsection{Isolation of sulfur-oxidizing bacteria}

Sulfur-oxidizing bacteria were isolated from sulfide polluted water samples by using direct plating method (Visser et al., 1997). The water sample (0.5 mL) was poured onto thiosulfate agar and broth media contained $5.0 \mathrm{~g} \mathrm{Na}_{2} \mathrm{~S}_{2} \mathrm{O}_{3}, 0.1 \mathrm{~g} \mathrm{~K}_{2} \mathrm{HPO}_{4}, 0.2 \mathrm{~g} \mathrm{NaHCO}_{3}, 0.1 \mathrm{~g}$ $\mathrm{NH}_{4} \mathrm{Cl}$ and $1000 \mathrm{ml}$ distilled water, $\mathrm{pH}$ 8.0. $0.0025 \mathrm{~g}$ of Bromo phenol blue (BPB) was added as an indicator (Vidyalakshmi et al., 2007). Then incubated at $30^{\circ} \mathrm{C}$ up to $72 \mathrm{~h}$, the $\mathrm{pH}$ of the broth inoculated medium were measured at $24 \mathrm{hrs}$ intervals. The bacterial isolate which were found to able to reduce maximum $\mathrm{pH}$ and color of the broth medium were further selected for their sulfate ion determination ability test.

\subsection{Screening of sulfur-oxidizing bacteria}

It was performed by inoculating bacterial inoculums into sulfur-oxidizer broth medium (Asku et al.,1991). The cultures were then incubated with agitation at 200 $\mathrm{rpm}$ at $30^{\circ} \mathrm{C}$ until the optical density $\left(O D_{600}\right)$ of the cultures reached $0.6-0.8$. The cultures were centrifuged at $4000 \mathrm{rpm}, 4^{\circ} \mathrm{C}$ for 30 minutes. Sulfide oxidase activity and protein concentration were assessed in the supernatant. The highest sulfide oxidase producers bacterial isolates were selected for further studies.

\subsection{Sulfate ion production}

The amount of sulfate ion ( $\mathrm{SO}^{2-}$ ) produced during growth of sulfur-oxidizing bacteria on thiosulfate broth medium was measured spectrophotometrically. Barium chloride solution $(10 \% \mathrm{w} / \mathrm{v})$ was added $(1: 1)$ to bacterial culture supernatant; the mixture was mixed vigorously (Cha et al.,
1999). The positive results were indicated by white turbidity due to barium sulfate formation which measured with spectrophotometer at $450 \mathrm{~nm}$. The obtained data was compared with the calibration curve using potassium sulfate $\left(\mathrm{K}_{2} \mathrm{SO}_{4}\right)$ as standard (Kolmert et al., 2000).

\subsection{Sulfide oxidase assay}

The enzyme activity was determined quantitively by measuring the product of enzymatic reaction in the form of sulfate $\left(\mathrm{SO}^{2-}\right)$ (Hirano et al. 1996) method. The reaction mixture contain $4.5 \mathrm{~mL}$ of $0.1 \mathrm{M}$ sodium acetate buffer ( $\mathrm{pH} 5.6$ ) and $1 \mathrm{~mL}$ supernatant, then $0.5 \mathrm{~mL}$ freshly prepared sodium sulfide $\left(\mathrm{Na}_{2} \mathrm{~S}\right)$ solution $(0.06 \mathrm{~g}$ $\mathrm{Na}_{2} \mathrm{~S}, 0.16 \mathrm{~g} \mathrm{NaOH}, 0.02$ g EDTA Na${ }_{2} .2 \mathrm{H}_{2} \mathrm{O}, 2 \mathrm{~mL}$ glycerol and $40 \mathrm{~mL}$ distilled water). The mixture was incubated at $30^{\circ} \mathrm{C}$ for 30 minutes and the reaction was subsequently stopped by the addition of $1.5 \mathrm{~mL} \mathrm{NaOH}(1.0 \mathrm{M})$ with mixing. Concentration of sulfate ion formed during sulfide oxidase assay was assessed through white turbidity by measuring absorbance at $450 \mathrm{~nm}$ using spectrophotometer. The amount of turbidity formed is proportional to the sulfate concentration in the sample. One unit of sulfide oxidase activity was defined as an amount of the enzyme required to produce $1 \mu \mathrm{mol}$ sulfate/hour/mL (U/mL).

\subsection{Identification of the bacterial isolates}

The bacterial isolates were presumptively identified based on morphological examination (colony characteristics, shape, spore, motility, Gram's reaction) and some biochemical characterization which described by MacFaddin (1980) (catalase production, lactose fermentation, Indole production, starch hydrolysis, gelatin hydrolysis, Growth at different $\mathrm{pH}$ and temperature), and growth on differential medium (MacConkey agar, Endo agar medium). The bacterial identification was carried out following the standard methods described in Bergey's Manual of Determinative Bacteriology (Holt et al., 1994).

\subsection{Optimization culture condition of bacterial isolate SOB4}

2.7.1. Effect of initial $\mathrm{pH}$ values on sulfide oxidase activity and sulfate ion production by bacterial isolate SOB4

The bacterial isolate was grown on thiosulfate broth medium at different initial $\mathrm{pH}$ varied between 5 and 9 . The initial $\mathrm{pH}$ was adjusted by $0.1 \mathrm{HCl}$ or $0.1 \mathrm{NaOH}$.

2.7.2. Effect of different concentrations of thiosulfate on sulfide oxidase activity and sulfate ion production by bacterial isolate SOB4

Different concentrations of thiosulfate 5, 10, 15, 20, 25 and $30 \mathrm{mg}$ per liter were supplemented into broth medium in $100 \mathrm{ml}$ Flasks. Media were inoculated by bacterial isolate under investigation. The flasks were then incubated at $30^{\circ} \mathrm{C}$ for $48 \mathrm{~h}$.

\subsection{Statistical analysis}

Statistical analysis was performed by SPSS, version 10 for windows (SPSS Inc; Chicago, IL, USA). Basic statistical parameters (mean and standard deviation) were estimated. 


\section{Results and discussion}

\subsection{Sulfur-oxidizing bacteria isolated from polluted water}

Isolation of potential sulfur-oxidizing bacteria was initiated from sewage and also industrial wastes (Sawada, 2006). The bacterial isolation was initiated by direct plating of water sample onto solid thiosulfate medium using the spread plate technique. A total of 20 colonies of sustainable sulfur-oxidizing bacteria were isolated from 8 polluted water samples. Morphologically differentiated bacterial isolates forming different colony appearance on agar medium were isolated and inoculated on thiosulfate broth medium containing bromophenol blue (BPB) as an indicator (Figures 1). The bacterial isolates were picked and streaked onto thiosulfate agar medium to obtain a pure culture (Madigan et al., 2000).

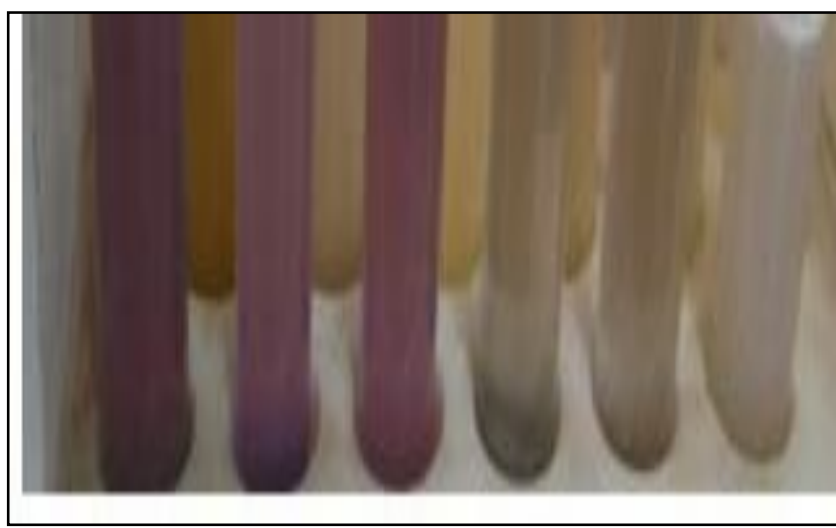

Figure 1. Growth of sulfur-oxidizing bacteria on thiosulfate broth supplied with bromophenol blue as an indicator

It was found that, bacterial isolates were able to change the color of the BPB in thiosulfate broth medium by reducing the $\mathrm{pH}$ of the medium from initial $\mathrm{pH}$ 8.0. From these only 2 isolates (SOB5 and SOB9) highly decreased the $\mathrm{pH}$ of the medium. The SOB isolates obtained from the polluted water samples could reduce the $\mathrm{pH}$ from 8.0 up to 5 in thiosulfate broth within 11 days of incubation. The ability of sulfur oxidizing bacteria to reduce medium $\mathrm{pH}$ was also reported by Donati et al. (1996). The $\mathrm{pH}$ reduction of the growth medium by sulfur oxidizing bacteria as a result of the production of sulfuric acid and oxidation of sulfide to sulfate ion (Behera et al., 2014).

In total twenty isolates were obtained from different samples of the sulfur oxidizing medium plate. From their isolates 11 isolates were selected based on their $\mathrm{pH}$ reduction ability on bromophenol blue containing thiosulfate broth and agar media, turning the color of media from purple to colorless (Figure 1). These bacterial isolates were considered as efficient sulfur oxidizing bacteria (SOB 1-11).

\subsection{Sulfate ion production}

The ability of bacterial isolates to produce sulfate ion was investigated. It could be clearly seen from Figure (2) that, among the 11 isolates tested, isolate SOB-9 showed maximum sulfate ion concentration $(155.12 \mathrm{mg} / \mathrm{ml})$ followed by the isolate SOB-4 $(125.73 \mathrm{mg} / \mathrm{ml})$, while minimum sulfate ion concentration was produced by the isolate SOB-6 $(79.65 \mathrm{mg} / \mathrm{ml})$. In this respect, Ravichandra et al. (2007) reported the maximum sulfate ion production $14-150 \mathrm{mg} / \mathrm{ml}$ by a Thiobacillus spp., these finding were relatively lower than that obtained in the present study. Similar results were obtained by Babana et al. (2011) who reported the highest sulfuric acid concentration ( $243 \mathrm{mg} / \mathrm{l}$ ) by a bacterial strain ATTC55128 followed by AHB436 $(230 \mathrm{mg} / \mathrm{l})$. The current results revealed that all the SOB produced high amount sulfate ion from $\mathrm{Na}_{2} \mathrm{~S}_{2} \mathrm{O}_{3}$ supplied in the medium.

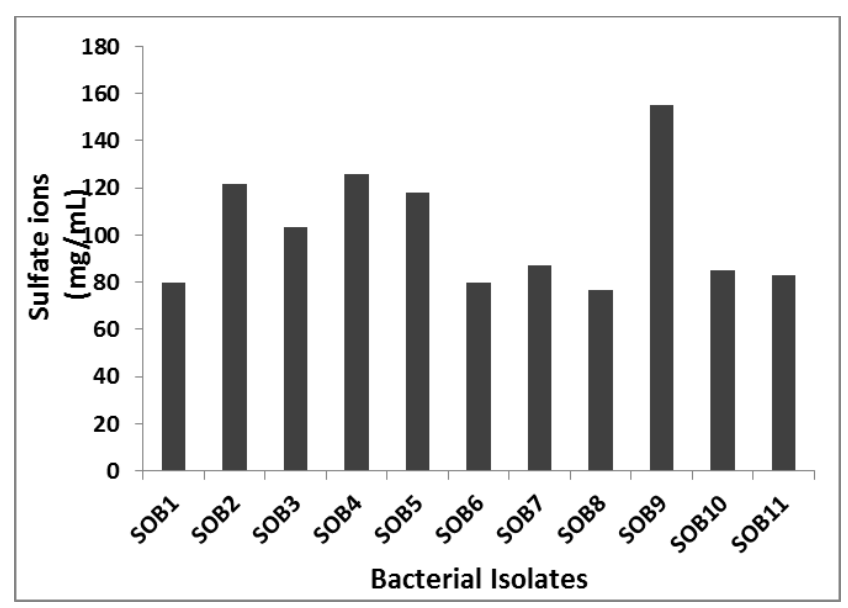

Figure 2. Sulfate ion production by eleven sulfur oxidizing bacterial isolates

\subsection{Sulfide oxidase activity}

Bacterial isolates were inoculated in the thiosulfate medium to detect their sulfur oxidase production (Figure 3). Generally, the enzyme activities of 11 isolates tested ranged from 2.68 to $5.23 \mathrm{U} / \mathrm{ml} / \mathrm{min}$. From which isolates SOB9, SOB5 and SOB3 were the highest producers (5.23, 4.17 and 4.07 respectively). Rohwerdert and Sand (2003) reported that, sulfur dioxygenase activity produced by Acidothiobacillus and Acidiphilium spp of $5.0 \pm 1.7$ and $373 \pm 90 \mathrm{nmol} / \mathrm{min} / \mathrm{mg}$ respectively. Similarly Nakada and Ohta (2000) reported the crude sulfur oxidase extract activity of 11.7 units by Bacillus spp. Crude extract of thiosulphate oxidase from Pseudomonas aeruginosa showed maximum activity of $130 \mathrm{U} / \mathrm{ml}$, as reported previously by Schook and Berk (1979). It is worthy to mention that, highly sulfide oxidase producers bacterial isolates ( 3 isolates) shown also maximum sulfate ion productions, resulting in reduction of media $\mathrm{pH}$ and this was clearly observed in SOB9, SOB5 and SOB4.

\subsection{Identification of the bacterial strains}

The eleven selected bacterial isolates were characterized by various morphological and biochemical features shown in Table (1). The Microscopic observation of the isolates revealed that most of them are rod shaped, motile and variable towards Gram's stain. Biochemical characteristics of microorganism were studied to identify the genus and species of unknown bacteria. Microorganisms are extremely versatile and their range of metabolic capabilities is very large (Norrell and Messley, 2003). 
These characteristics such as, gram stain, spore formation, motility, catalase, indole, hydrolysis of gelatin and starch, can be used to demonstrate the exceptional metabolic diversity of prokaryotic organisms and aid in differentiation between closely related genera or species (MacFaddin, 1980). The bacterial isolates SOB1, SOB4, SOB7 and SOB11 were found to be Bacillus spp., SOB5 and SOB9 were tentatively assigned to the Pseudomonas spp. and SOB10 as Micrococcus sp., other three bacterial isolates SOB 2, SOB3, SOB8 belong to Klebsiella spp. Most of the heterotrophic bacteria, involve in sulfur oxidation

Table 1. Biochemical characteristics of Sulfur oxidizing bacterial isolates. SOB is Sulfur oxidizing bacteria, ( - ) is Not Detected

\begin{tabular}{|c|c|c|c|c|c|c|c|c|c|c|c|}
\hline Characters & SOB1 & SOB2 & SOB3 & SOB4 & SOB5 & SOB6 & SOB7 & SOB8 & SOB9 & SOB10 & SOB11 \\
\hline Shape & Rods & $\begin{array}{l}\text { Short } \\
\text { rods }\end{array}$ & $\begin{array}{l}\text { Short } \\
\text { rods }\end{array}$ & rods & $\begin{array}{l}\text { Short } \\
\text { rods }\end{array}$ & rods & rods & $\begin{array}{l}\text { Short } \\
\text { rods }\end{array}$ & $\begin{array}{l}\text { Short } \\
\text { rods }\end{array}$ & cocci & Rods \\
\hline Motility & - & + & + & - & + & - & + & + & + & - & - \\
\hline $\begin{array}{l}\text { Aerobic } \\
\text { growth }\end{array}$ & + & + & + & + & + & + & + & + & + & + & + \\
\hline Catalase & + & + & + & + & + & + & - & - & + & - & + \\
\hline Gram stain & G-ve & G-ve & G-ve & G+ve & G-ve & G-ve & G+ve & G-ve & G-ve & G-ve & G-ve \\
\hline $\begin{array}{l}\text { Lactose } \\
\text { fermentor }\end{array}$ & - & + & + & + & + & - & + & - & + & - & + \\
\hline $\begin{array}{c}\text { Indole } \\
\text { production }\end{array}$ & - & - & - & - & + & - & - & - & + & - & - \\
\hline $\begin{array}{c}\text { Gelatin } \\
\text { hydrolysis }\end{array}$ & + & - & + & - & ++ & - & + & - & ++ & - & - \\
\hline $\begin{array}{c}\text { Starch } \\
\text { hydrolysis }\end{array}$ & ++ & - & + & + & - & + & ++ & ++ & - & - & - \\
\hline Cellulase & - & - & - & + & - & - & - & - & - & - & + \\
\hline $\begin{array}{c}\text { Growth at } \\
\text { pH 5- }\end{array}$ & + & + & + & + & + & + & + & + & + & + & + \\
\hline $\begin{array}{c}\text { Growth at } \\
40^{\circ} \mathrm{C}\end{array}$ & + & + & + & + & + & + & + & + & + & + & + \\
\hline
\end{tabular}

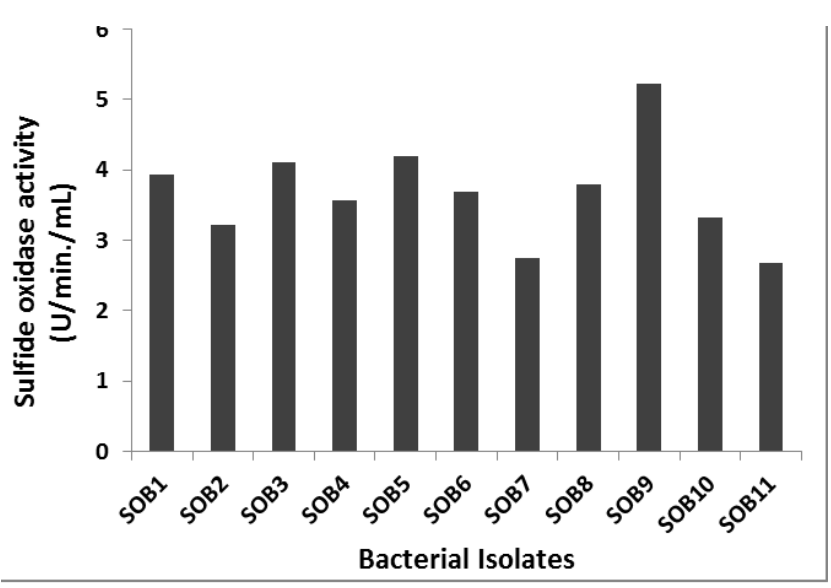

Figure 3. Sulfide oxidase activity of eleven sulfur oxidizing bacteria

\subsection{Optimization culture condition of bacterial isolate SOB4}

The growth rate of bacteria and their metabolism depend on the composition of the medium and the prevalent environmental conditions. Various bacterial strains differ in their nutritional requirements and cultural conditions for optimal growth and enzyme production. In the present study, an optimization for the production of sulfide belong to the genera Pseudomonas (Sorokin et al., 1999), Xanthobacter (Cho et al., 1992), Escherichia coli (Starkey et al., 1935) were also reported earlier. Behera et al. (2014) suggested that the sulfur oxidizing bacteria isolated from Mangrove soil related to Bacillus, Pseudomonas and Micrococcus spp. Most of the heterotrophic SOB bacteria reported previously were found to belong to the genera Pseudomonas, Paracoccus, Bacillus, Xanthomonas, Halomonas, Escherichia coli and Klebsiella (Gommers and Kuenen, 1988; Mustafa et al., 2015). 
well as the production of sulfate ion in the bacterial medium. The results in figure (4) showed that, the highest sulfide oxidase activity $(5.5 \mathrm{U} / \mathrm{min})$ was detected at $\mathrm{pH}$ 6.0. There was no significant difference between the values of sulfate ion concentration at $\mathrm{pH} 6.0$ and 7.0 while its concentration at the first was slightly higher than the last $(41.7 \mathrm{mg} / \mathrm{ml})$. On the other hand, at high acidic and alkaline $\mathrm{pH}$ values, the induction of enzyme and production of sulfate ion were significantly low. Behera et al. (2016) mentioned that, the maximum production of sulfide oxidase by Klebsiella sp. was observed at $\mathrm{pH}$ 7.0.

From the previous results, it could be concluded that, the optimum $\mathrm{pH}$ value that suitable for induction of sulfide oxidase as well as production of sulfate ion was $\mathrm{pH}$ 6.0.

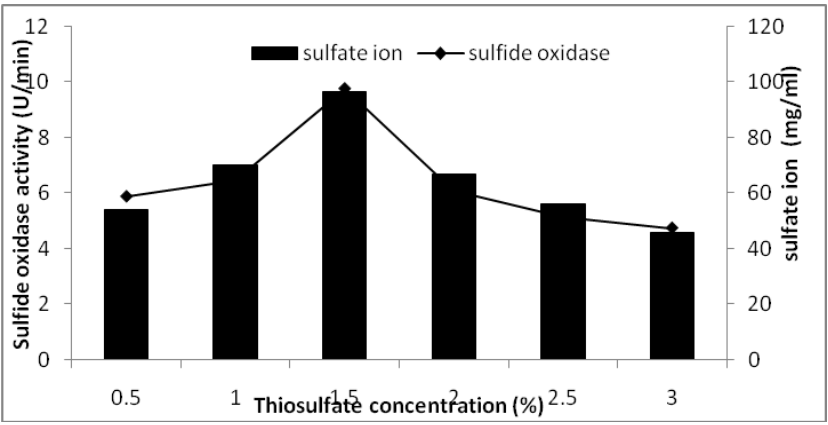

Figure 5. Effect of thiosulfate concentrations on sulfide oxidase activity and sulfate ion production of SOB4

\subsection{Effect of thiosulfate concentraction on sulfide oxidase activity and sulfate ion production by Bacillus sp.}

Thiofulfate concentration is playing a critical role in the activity of sulfure oxidizing bacteria. This may be due to, thiosulfate is the stimulator of sulfide oxidase enzyme. The results in figure (5) showed that, the sulfide oxidase enzymes results was going parallel with the results of the produced sulfate ion. Meaning that, any increase in the enzyme activity was followed by increase sulfate ion. The optimum concentration of thiosulfate concentration was $1.5 \%$. At this concentration, the activity of sulfide oxidase was $9.78 \mathrm{U} / \mathrm{min}$ while the sulfate ion was $96.6 \mathrm{mg} / \mathrm{ml}$. At $3 \%$ of thiosulfate, the lowest sulfate ion concentration was detected $45.9 \mathrm{mg} / \mathrm{m}$. this may be due to the lowest induction of enzyme at this concentration. From the results, it could be observed that, there was a close relationship between the enzyme activity and sulfate ion production. Additionally, the thiosulfate concentration (substrate) is a critical factor that affecting the enzyme activity that subsequently affecting on sulfate ion production. Behera et al. (2016) observed that, The induction of sulfate ion and sulfide oxidase enzyme by Klebsiella sp. decrease by increasing the thiosulfate above $10 \mathrm{mg} / \mathrm{ml}$. Many literatures mentioned that, the high concentration of thiosulfate decrease the bacterial capacity to convert it to sulfate ion because it may cause toxic affect on the bacterial growth (Skirnisdottir et al., 2011).

\section{Conclusion}

From the previous results, it could be concluded that all tested bacterial isolates exhibited decrease in the $\mathrm{pH}$ value and capability to produce sulfate ion in the culture medium. The sulfur oxidizing bacteria isolated in this study by as well as the production of acid may encourage the utilization of these bacteria in reclamation of alkali soils. Using of these SOB as bio-inoculants can be incorporated to enhance sulfur oxidation in soil and to increase availability of sulfate to minimize S-fertilizers application and reduce environmental pollution and promotes sustainable agriculture.

\section{References}

Asku Z., Kutsal T., Gun S., Haciosmanogk N. and Gholminesad M. (1991), Investigation of biosorption of natrium, Sulfate, Cuprum (II) and Nickel (II) ions to activated sludge bacteria, Environmental Technology, 12, 915-921.

Babana A.H, Samake F. and Maiga K. (2011), Characterization of some agricultural soils: presence and activity of tilemsi rock phosphate-solubilizing Thiobacilli, British Microbiology Research Journal, 1(1), 1-9.

Behera1 B.C., Patra M., Dutta S.K., Thatoi H.N. (2014), Isolation and characterization of sulfur oxidising bacteria from mangrove soil of mahanadi river delta and their sulfur oxidizing ability, Journal of Applied \& Environmental Microbiolohy, 2(1), 1-5.

Behera, B.C., Singh, S.K., Patra, M., Mishra, R.R., Sethi, B.K., Dutta, S.K., and Thatoi, H.N. (2016), Partial purification and characterisation of sulphur oxidase from Micrococcus sp. and Klebsiella sp. isolated from mangrove soils of Mahanadi river delta, Odisha, India, Universal Journal of Microbiology Research, 4, 66-78.

Cho K.S., Hirai M. and Shoda M. (1992), Degradation of hydrogen sulfide by Xanthomonas sp. Strain DY44 Isolated from Peat, Applied and Environmental Microbiology, 58(4): 1183-1189.

Cho K.S., Zhang L., Hirai M. and Shoda M. (1991), Removal characteristics of hydrogen sulfide and methanethiol by thiobacillus sp. isolated from peat inbiologicaldeodarization, Journal of Fermentation and Bioengineering, 71, 44-49.

Donati E., Curutchet G., Pogliani C. and Tedesco P.H. (1996), Bioleaching of covellite using pure and mixed cultures of Thiobacillus ferrooxidans and Thiobacillus thiooxidans, Process Biochemistry, 31, 129-134.

Gommers P.J.F. and Kuenen J G. (1988), Thiobacillus Strain Q, a Chemolithoheterotrophic Sulfur Bacterium, Archives of Microbiology, 150, 117-125.

Hirano T., Kurosawa H., Nakamura K. and Amano Y. (1996), Simultaneous removal of hydrogen sulphide and trimethylamine by a bacterial deodorant. Journal of Fermentation and Bioengineering, 81, 337-342.

Holt J.G., Krieg N.R., Sneath P.H.A., Staley J.T. and Williams S.T. (1994), Bergey's Manual of Determinative Bacteriology, 9th ed, Williams and Wilkins, Maryland, U.S.A.

Kolmert, W.m.P. and Hallberg K.B. (2000), A fast and simple turbidimetric method for the determination of sulfate in sulfate-reducing bacterial cultures, Journal of Microbiology Methods, 41, 179-184. 
MacFaddin J.F. (1980). Biochemical Tests for Identification of Medical Bacteria. 2nd ed. Williams and Wilkins, Baltimore, London.

Madigan M.T., Martinko J.M. and Parker J. (2000), Brock Biology of Microorganism, 9th ed. Prentice-Hall, Upper Saddle River, N. J.

Mustafa I., Ohta H., Niidone T. and Morimura S. (2015), Isolation of heterotrophic thiosulfate-oxidizing bacteria and their role in the Ariakesea, Japan, Journal of Ecology and the Natural Environment, 7(4), 106-112.

Nakada Y. and Ohta Y. (1999), Purification and properties of hydrogen sulfide oxidase from Bacillus sp, BN53-1, Journal of Bioscience and Bioengineering's, 87(4), 452-455.

Norrell S.A. and Messley K.E. (2003), Principles and Applications: Microbiology Laboratory Manual. 2nd ed., Prentice-Hall, Upper Saddle River, N.J.

Pokorna D. and Zabranska J. (2015), Sulfur-Oxidizing bacteria in environmental technology. Biotechnology Advances, 33, 1246-1259.

Ravichandra P., Mugeraya G., Ganganirao A., Ramakrishna M. and Jetty A. (2007), Isolation of Thiobacillussp from aerobic sludge of distillery and dairy effluent treatment plants and its sulfide oxidation activity at different concentrations, Journal of Environmental Biology, 28(4), 819-823.

Rohwerdert R. and Sand W. (2003), The sulfane sulfur of persulfides is the actual substrate of the sulfur-oxidizing enzymes from Acidithiobacillus and Acidiphilium sp, Microbiology, 149, 1699-1709.

Sawada T. (2006), Production and application of effective microorganisms (EM) around the world.em technology application workshop, April 17-18. Johor, Malaysia.

Schook L. B. and Berk R.S. (Mar. 1979), Nutritional studies with Pseudomonas aeruginosa grown on inorganic sulfur sources, Journal of Bacteriology, 133, 1377-1382.

Skirnisdottir S., Hreggvidson G.O., Holst O. and Kristjansson J.K. (2001). Isolation and characterization of a mixotrophic sulfur-oxidizing thermus scotoductus. Extremophile, 5, 45-51.

Sorokin D.Y., Teske A., Robertson L.A. and Kuenen J. G. (1999), Anaerobic oxidation of thiosulfate to tetrathionate by obligately heterotrophic bacteria, belonging to the Pseudomonas stutzeri group, FEMS Microbiol Ecology, 30, 113-123.

Starkey R.L. (1935), Isolation of some bacteria which oxidize thiosulfate, Soil Science, 39, 197-219.

Vidyalakshmi R. and Sridar R. (2007), Isolation and characterization of sulfur oxidizing bacteria, Journal of Culture Collection, 5, 73-77.

Visser J. M., Robertson L.A., Verseveld H.W.V. and Kuenen J.G. (Jun. 1997), Sulfur production by obligately chemolithoautotrophic Thiobacillus species, Applied and Environmental Microbiology, 63(6), 2300-2305. 